http://dx.doi.org/10.11646/phytotaxa.166.3.3

\title{
Surirella arctica comb. et stat. nov. (Bacillariophyta)—a rare arctic diatom
}

\author{
JANA VESELÁ ${ }^{1} \&$ MARINA POTAPOVA ${ }^{2}$ \\ ${ }^{1}$ Department of Botany, Faculty of Science, University of South Bohemia, Na Zlaté stoce 1, České Budějovice, CZ-370 05, Czech \\ Republic. E-mail: scope@centrum.cz (corresponding author) \\ ${ }^{2}$ Diatom Herbarium, The Academy of Natural Sciences, Drexel University, 1900 Benjamin Franklin Parkway, Philadelphia, \\ Pennsylvania, 19103, USA. E-mail: potapova@ansp.org
}

\begin{abstract}
Surirella terryi var. arctica has been described more than 50 years ago from northern Alaska. Since then, it has not been reported in the scientific literature except for a single record. We studied in detail the holotype slide and material of $S$. terryi var. arctica and several other samples from northern Alaska, and concluded that $S$. terryi var. arctica differs from the nominate variety and should be placed in a separate species. Surirella arctica comb. et stat. nov. is presented here including a detailed morphological description and light and scanning electron micrographs. Surirella arctica can be easily recognized due to the internally thickened median area and transverse costae, together forming a craticula-like structure on the interior valve surface. This feature is well visible in the light microscope and helps discriminating $S$. arctica from other Surirella species similar in valve shape, size and other morphological characters. These taxa include $S$. angusta, $S$. heardensis and an unknown species from Siberia and Mongolia. The presence of S. arctica has been confirmed to date only from the northern Alaska and likely from the high Arctic in Canada.
\end{abstract}

Key words: Surirella arctica, Surirella terryi, Surirella angusta, Alaska, diatoms

\section{Introduction}

In the few past years there has been considerable effort to describe the diversity of freshwater diatoms in North America as it became obvious that many diatom species are not cosmopolitan and identification of North American diatoms with European taxonomic keys is inappropriate. This effort has resulted in the description of many new species of diatoms (e.g., Gaiser \& Johansen 2000, Bahls 2012, 2013, Stepanek \& Kociolek 2013), in publishing of regional diatom floras (e.g., Siver et al. 2005, Antoniades et al. 2008, Zimmermann et al. 2010, Siver \& Hamilton 2011), and establishment of an updateable online diatom identification guide "The Diatoms of the United States" (Spaulding et al. 2010). In addition, the identities of several rarely reported or forgotten taxa described in the past from North America have recently been clarified (e.g., Kociolek et al. 2011, Van de Vijver \& Lange-Bertalot 2009, Potapova 2013, Veselá et al. 2013).

While studying in detail Surirella terryi D.B. Ward ex W.A. Terry (1907: 127), one of those rare almost forgotten diatoms from the Northeastern USA (Veselá et al. 2013), we investigated the type material of $S$. terryi var. arctica R.M. Patrick \& Freese (1961: 285). This variety was described more than 50 years ago from Alaska but has not been reported since, except for a single record made by Foged (1981: 169). The original description of $S$. terryi var. arctica is thus:

"Valve linear with wedge-shaped, rounded apices. Apical axis marked by a clear narrow line. Alae 5-6 in $10 \mu$, narrow. Surface of valve striated. Striae, 22-30 in $10 \mu$. Length, 26-49 $\mu$. Breadth, 6-8 $\mu$. This variety is distinguished from the nominate variety, Surirella terryi Ward var. terryi, by the shape of the ends of the valve and the number of the alae" (Patrick \& Freese 1961: 285). 
Remarkably, "S. spec.", or a very similar taxon to "S. spec.", was also reported by Foged (1982: pl. 35, fig. 19) from Borholm, Denmark and by Metzeltin et al. (2009) from Mongolia, both under the name Surirella angusta Kützing. However, Metzeltin et al. (2009), in our opinion, included several taxa under the name S. angusta. We found that one group is identical to " $S$. spec." (pl. 241, figs 1-7, 9-14), none of the taxa belong to $S$. angusta Kützing, and one SEM photograph (pl. 242, fig. 6) may represent S. arctica. Unfortunately, Metzeltin et al. (2009) did not publish any LM photographs corresponding to $S$. arctica, which creates some uncertainty about the identity of the diatom from pl. 242, fig. 6 .

Finally, there is a record of an unidentified species "Surirella sp. [cf. S. angusta Kützing 1844]" (further called "S. sp.") in Antoniades et al. (2008; p. 296, pl. 79, figs 1-5, pl. 132, figs 7-9) from Ellef Ringnes Island, Canada. The authors described the species in detail therefore it is possible to compare it with $S$. arctica; we conclude that their specimens belong to $S$. arctica. The overall valve appearance resembles $S$. arctica as well as the ranges of all valve characteristics measured (Table 2 ). The specimens of " $S$. sp." probably belong to the smaller end of the valve length range (28-36.2 $\mu \mathrm{m})$ observed for $S$. arctica. If we are correct, $S$. arctica does not occur only around Driftwood, Alaska but also in Ellef Ringnes Island, Canada (two freshwater and circumneutral sites with very low specific conductances, DOC and nutrient concentrations), which indicates that $S$. arctica is probably distributed in the high Arctic of North America (north of $68^{\circ} \mathrm{N}$ latitude).

\section{Acknowledgements}

The use of the Centralized Research Facilities, Drexel University, for the SEM is gratefully acknowledged. We thank Prof. Bart Van de Vijver for providing pictures of Surirella angusta from the Kützing's type material for our comparisons. Jana Veselá is grateful for two separate McHenry Fellowships which supported her stay during 2011 and 2012 at the Academy of Natural Sciences of Drexel University in Philadelphia, and allowed her to work on this project. Jana Veselá also received assistance from the University of South Bohemia, through a grant to the Botany Department (GAJU \# 138/2010/P).

\section{References}

Antoniades, D., Hamilton, P.B., Douglas, M.S.V. \& Smol, J.P. (2008) Diatoms of North America: The freshwater floras of Prince Patrick, Ellef Ringnes and northern Ellesmere Islands from the Canadian Arctic Archipelago. Iconographia Diatomologica 17: 1-649.

Bahls, L. (2012) Seven new species in Navicula sensu stricto from the Northern Great Plains and Northern Rocky Mountains. Nova Hedwigia Supplement 141: 19-37.

Bahls, L. (2013) New diatoms (Bacillariophyta) from western North America. Phytotaxa 82: 7-28. http://dx.doi.org/10.11646/phytotaxa.82.1.2

Foged, N. (1981) Diatoms in Alaska. Bibliotheca Phycologica 53: 1-317.

Foged, N. (1982) Diatoms in Bornholm, Denmark. Bibliotheca Phycologica 59: 1-175.

Gaiser, E.E. \& Johansen, J.R. (2000) Freshwater diatoms from Carolina bays and other isolated wetlands on the Atlantic Coastal Plain of South Carolina, U.S.A., with description of seven taxa new to science. Diatom Research 15: 75-130. http://dx.doi.org/10.1080/0269249X.2000.9705487

Hustedt, F. (1942) Süßwasser-Diatomeen des indomalayischen Archipels und der Hawaii-Inslen. Internationale Revue der gesamten Hydrobiologie und Hydrographie 42: 1-252.

Kociolek, J.P., Graeff, C.L. \& Thomas, E.W. (2011) A description of the frustular morphology of Frustulia creuzburgensis (Krasske) Hustedt, with comments on its systematic position. Diatom Research 26: 29-41. http://dx.doi.org/10.1080/0269249X.2011.562421

Krammer, K. \& Lange-Bertalot, H. (1988) Bacillariophyceae: Bacillariaceae, Epithemiaceae, Surirellaceae. In: Ettl, H., Gerloff, J., Heynig, H. \& Mollenhauer, D. (eds.) Süßwasserflora von Mitteleuropa, 2/2. Gustav Fisher Verlag, Stuttgart, New York, 596 pp.

Kützing, F.T. (1844) Die kieselschaligen Bacillarien oder Diatomeen. Nordhausen. 152 pp., 30 pls.

Lange-Bertalot, H. \& Genkal, S.I. (1999) Diatomeen aus Sibirien I. Inseln im Arktischen Ozean (Yugorsky Shar Strait). Iconographia Diatomologica 6: 1-363.

Metzeltin, D., Lange-Bertalot, H. \& Nergui, S. (2009) Diatoms in Mongolia. Iconographia Diatomologica 20: 1-684.

Patrick, R. \& Freese, L.R. (1961) Diatoms (Bacillariophyceae) from Northern Alaska. Proceedings of the Academy of Natural Sciences of Philadelphia 112: 129-293. 
Potapova, M. (2013) The types of 22 Navicula (Bacillariophyta) species described by Ruth Patrick. Proceedings of the Academy of Natural Sciences of Philadelphia 162: 1-23. http://dx.doi.org/10.1635/053.162.0101

Potapova, M. \& English, J. (2010) Surirella angusta. Diatoms of the United States. Available from: http:// westerndiatoms.colorado.edu/taxa/species/surirella_angusta (23 August 2013).

Rott, E. (1995) Diatoms of the Grand River, Ontario, Canada, restudied after 25 years. Limnologica 25: $165-192$.

Ruck, E.C. \& Kociolek, J.P. (2004) Preliminary phylogeny of the family Surirellaceae (Bacillariophyta). Bibliotheca Diatomologica 50: 1-236.

Sala, S.E. (1996) Flora diatomologica del embalse Paso de las Piedras (Argentina). III. Familias Epithemiaceae, Bacillariaceae y Surirellaceae (O. Pennales). Cryptogamie, Algologie 17: 95-122.

Sgro, G.V. \& Johnasen, J.R. (1995) Rapid bioassessment of algal periphyton in freshwater streams. In: Butterworth F.M., Corkum L.D. \& Guzmán-Rincón J. (eds.) Biomonitors and biomarkers as indicators of environmental change. Plenum Press, New York, pp. 291-311.

Siver, P.A. \& Hamilton, P.B. (2011) Diatoms of North America: The Freshwater Flora of Waterbodies on the Atlantic Coastal Plain. Iconographia Diatomologica 22: 1-916.

Siver, P.A., Hamilton, P.B., Stachura-Suchoples, K. \& Kociolek, J.P. (2005) Diatoms of North America. The Freshwater Flora of Cape Cod. Iconographia Diatomologica 14: 1-463.

Spaulding, S.A., Lubinski, D.J. \& Potapova, M. (2010) Diatoms of the United States. Diatom identification guide \& ecological resource. US Geological Survey, Boulder CO, USA. Available from: http://westerndiatoms.colorado.edu/ (accessed: 28 August 2013).

Stepanek, J.G. \& Kociolek, J.P. (2013) Several new species of Amphora and Halamphora from the western USA. Diatom Research 28: 61-76. http://dx.doi.org/10.1080/0269249X.2012.735205

Terry, W.A. (1907) A partial list of Connecticut diatoms with some account of their distribution in certain parts of the state. Rhodora 9: 125-140.

Van de Vijver, B., Cocquyt, C., de Haan, M., Kopalová, K. \& Zidarova, R. (2013) The genus Surirella (Bacillariophyta) in the sub-Antarctic and maritime Antarctic region. Diatom Research 28: 93-108. http://dx.doi.org/10.1080/0269249X.2012.739975

Van de Vijver, B. \& Lange-Bertalot, H. (2009) New and interesting Navicula taxa from Western and Northern Europe. Diatom Research 24: 415-429. http://dx.doi.org/10.1080/0269249X.2009.9705811

Veselá, J., Johansen, J.R. \& Potapova, M. (2013) Surirella terryi and S. cruciata: two rare diatoms from North America. Diatom Research 28: 503-516. http://dx.doi.org/10.1080/0269249X.2013.853697

Zimmermann, C., Poulin, M. \& Pienitz, R. (2010) Diatoms of North America: The Pliocene-Pleistocene freshwater flora of Bylot Island, Nunavut, Canadian High Arctic. Iconographia Diatomologica 21: 1-407. 